$5-15$

SANDIA REPORT

SAND95-0430 - UC-1243

Unlimited Release

Printed April 1995

\title{
PETROLEUM AND GEOTHERMAL PRODUCTION TECHNOLOGY IN RUSSIA: Summary of Information Obtained During Informational Meetings with Several Russian Institutes
}

Diane M. Schafer, David A. Glowka, Lawrence W. Teufel

Prepared by

Sandia National Laboratories

Albuquerque, New Mexico 87185 and Livermore, California 94550

for the United States Department of Energy

under Contract DE-ACO4-94AL85000

Approved for public release; distribution is unlimited. 


\section{DISCLAIMER}

This report was prepared as an account of work sponsored by an agency of the United States Government. Neither the United States Government nor any agency Thereof, nor any of their employees, makes any warranty, express or implied, or assumes any legal liability or responsibility for the accuracy, completeness, or usefulness of any information, apparatus, product, or process disclosed, or represents that its use would not infringe privately owned rights. Reference herein to any specific commercial product, process, or service by trade name, trademark, manufacturer, or otherwise does not necessarily constitute or imply its endorsement, recommendation, or favoring by the United States Government or any agency thereof. The views and opinions of authors expressed herein do not necessarily state or reflect those of the United States Government or any agency thereof. 


\section{DISCLAIMER}

Portions of this document may be illegible in electronic image products. Images are produced from the best available original document. 
Issued by Sandia National Laboratories, operated for the United States Department of Energy by Sandia Corporation.

NOTICE: This report was prepared as an account of work sponsored by an agency of the United States Government. Neither the United States Government nor any agency thereof, nor any of their employees, nor any of their contractors, subcontractors, or their employees, makes any warranty, express or implied, or assumes any legal liability or responsibility for the accuracy, completeness, or usefulness of any information, apparatus, product, or process disclosed, or represents that its use would not infringe privately owned rights. Reference herein to any specific commercial product, process, or service by trade name, trademark, manufacturer, or otherwise, does not necessarily constitute or imply its endorsement, recommendation, or favoring by the United States Government, any agency thereof or any of their contractors or subcontractors. The views and opinions expressed herein do not necessarily state or refiect those of the United States Government, any agency thereof or any of their contractors.

Printed in the United States of America. This report has been reproduced directly from the best available copy.

Available to DOE and DOE contractors from Office of Scientific and Technical Information

PO Box 62

Oak Ridge, TN 37831

Prices available from (615) 576-8401, FTS 626-8401

Available to the public from

National Technical Information Service

US Department of Commerce

5285 Port Royal Rd

Springfield, VA 22161

NTIS price codes

Printed copy: A03

Microfiche copy: A01 
Distribution

Category

UC-1243

SAND $95-0430$

Unlimited Distribution

Printed April 1995

\title{
PETROLEUM AND GEOTHERMAL PRODUCTION TECHNOLOGY IN RUSSIA: Summary of Information Obtained During Informational Meetings with Several Russian Institutes
}

\author{
Diane M. Schafer \\ David A. Glowka \\ Lawrence W. Teufel \\ Sandia National Laboratories \\ Albuquerque, NM 87185
}

\begin{abstract}
Russian scientists and engineers have drilled the deepest holes in the world. It is recognized that this experience has given them an expertise in drilling superdeep holes, as well as other aspects of drilling, completions, and geophysics. More and more US oil and gas companies are vigorously expanding their exploration and development into Russia. It is important for them to identify and use Russian technology in drilling, completion, logging, and reservoir characterization to the extent possible, in order to both reduce drilling costs and help support the Russian economy. While these US companies are interested in becoming involved in and/or sponsoring research in Russia, they have been unsure as to which scientists and institutes are working on problems of interest. It was also important to determine in which areas Russian technology is farther advanced than in the West. Such technology could then be commercialized as part of the Industrial Partnering Program. In order to develop a clear understanding of these issues, two Sandia engineers with drilling and completions expertise and a geophysicist with expertise in reservoir analysis traveled to Russia to meet with Russian scientists and engineers to discuss their technologies and areas of interest. This report contains a summary of the information obtained during the visit.
\end{abstract}




\section{ACKNOWLEDGMENTS}

This work was sponsored by the U. S. Department of Energy, Defense Programs, under the Industrial Partnering Program at Sandia National Laboratories under Contract DE-AC0494AL85000. 


\section{TABLE OF CONTENTS}

INTRODUCTION

GNPP Nedra

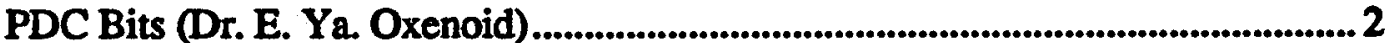

Downhole Motors (V. A. Shvetsky) ............................................................................2

Drilling Muds (Dr. E. Ya. Oxenoid) .............................................................................. 3

Cements (Y. M. Kurbanov)...................................................................................................... 4

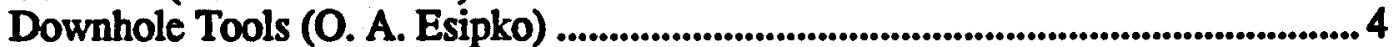

Drill Rigs (Dr. E. Ya. Oxenoid) .........................................................................5

Drill Pipe (Dr. E. Ya. Oxenoid) ..................................................................................... 5

Blowout Equipment (V. A. Shvetsky) .......................................................................... 5

Roller Cone and Core Bits (V. A. Shvetsky) ...............................................................5

Super-Deep Drilling (Dr. E. Ya. Oxenoid) ..............................................................6

Environmental Problems (Dr. E. Ya. Oxenoid) .............................................................6

State Oil and Gas Academy named after Gubkin .....................................................................6 6

Surface Geophysics (Dr. Miron Rapoport) .........................................................6

Seismic Research (Dr. Adam Urupov) .........................................................................6

Borehole Geophysics (Dr. Valery Dobrynin and Prof. Wieldenschten)...................6 6

Geology (Professor Victor Yermolkin)............................................................................ 6

All-Union Scientific Research Drilling Technologies Institute (VNIIBT)............................7 7

Vane Motors (Dmitre Baldenko) .................................................................................7

Turbines (Mr. Litvyak) ................................................................................................... 8

Coring (Alexander Saroykin) .........................................................................

Reamers, Hole Openers, and Other (Alexander Saroykin) ........................................8

Cone Bits (Vladimir Brajyentsev)....................................................................................9

Packers (Yuri Tsyrin and Leo Faroukshin) ......................................................................9

Solving Drilling Problems (Boris Kurochkin) ............................................................. 10

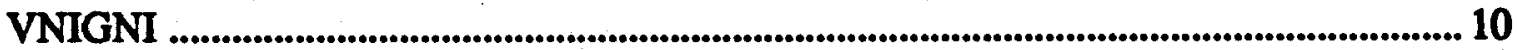

Mud Additives (Dr. Timokhin) ..................................................................................11

$\mathrm{H}_{2} \mathrm{~S}$ and $\mathrm{CO}_{2}$ Detection and Corrosion (Dr. Sukova) ..............................................11

Grouting Mixtures and Oil-Based Muds (Dr. Ogalykhen) ........................................ 11

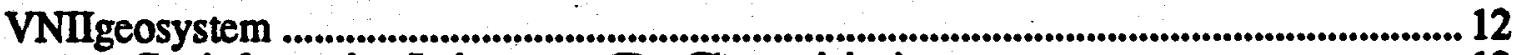

Geoinformation Laboratory (Dr. Cheremisina) ......................................................... 12

Drilling Technologies (Dr. Vorozhbitov) ......................................................... 13

Geochemical Instrumentation and Metrology (Dr. Valery Ruchnov) ..................... 13

Geoecological Lab (Dr. Suliko Chutkerashvili) ............................................................. 13

St. Petersburg Mining Institute ........................................................................................ 13

Geothermal Technology (Prof. Yuriy Dyadkin) ........................................................14

Foam Drilling (Vladimir Klimov)........................................................................14

Quick Setting Cements (Vladimir Klimov) ......................................................................... 14

VNIIgeofizika Neftegeofizika............................................................................................. 14 
POSSIBLE AREAS FOR COLLABORATION . 15

Appendix A - ADDRESSES OF VISITED INSTITUTES 16 


\section{INTRODUCTION}

In early October, 1994, Diane Schafer, David Glowka (Geothermal Research Department) and Larry Teufel (Geomechanics Department) spent just over two weeks in Russia meeting with various scientists and engineers to discuss possible joint research opportunities. Topics of discussions included: drilling, drilling fluids, cementing, logging, geothermal resource utilization, fractured reservoir analysis, geophysical studies, environmental remediation, and oil and gas exploration. The Sandia group met approximately 40 scientists and engineers at the following institutes:

Institute (location)

GNPP Nedra (Yaroslavl, Russia)

VNIGNI (Moscow Region, Russia)

Scientific Research Drilling Institute - VNIIBT (Moscow)

St. Petersburg Mining Institute (St. Petersburg, Russia)

State Gubkin Academy

of Oil and Gas (Moscow)

VNIIgeosystem (Moscow)

VNIIgeofizika Neftegeofizika (Moscow)
Specialty

Scientific and super-deep drilling, responsible for drilling (engineering and core analysis) the deepest hole in the world in the Kola peninsula; also, high temperature and specialty cements

Drilling muds

Drilling technology, especially downhole motors, bits, packers, and cementing practices

Geothermal resource utilization, foam drilling, and specialty cementing applications

Logging interpretation, geophysics, fractured reservoir analysis, oil and gas exploration

Geo-information systems, environmental remediation, geothermal drilling, geochemistry, near-surface reservoir analysis

Geophysical studies, seismic exploration, oil and gas exploration

The goal of the visit, funded under the Industrial Partnering Program, was to develop collaborative research projects between Sandia Labs, US industry, and research and development institutes in the Former Soviet Union. Information learned during the visit is documented in this report and will be distributed to interested US companies in order to identify areas of possible collaboration. Areas of possible joint interest discussed during our visit to Russia are detailed at the end of this report. Phone numbers and addressees of people with whom we met are included in Appendix A. 


\section{INFORMATION OBTAINED DURING DISCÚSSIONS}

During discussions with scientists and engineers at several different institutes in Russia, a wide variety of information was obtained. This information is detailed below. As this information was obtained during informal discussions, it is quite possible that errors in translation or simply misunderstandings occurred; however, the following contains our understanding of the areas discussed. No attempt has been made to verify the information received.

\section{GNPP Nedra}

The scientists and engineers at GNPP Nedra are responsible for the scientific super-deep drilling activities in Russia. Among the super-deep wells they have drilled is the Kola well, the deepest well in the world at over $12 \mathrm{~km}$. GNPP Nedra provides drilling engineering as well as comprehensive geological and geophysical data interpretation and analysis.

At GNPP Nedra in Yaroslavl, Russia, we met with several scientists and engineers including: Yaragui Kurbanov, Bilal Khakhaev, Vladilen Shvetsky, Alexander Borisenko, Lev Pevzner, Oleg Esipko, and E. Ya. Oxenoid. Our discussions concentrated on the areas of drilling and cementing.

PDC Bits (Dr. E. Ya. Oxenoid) - Cutters for their drag-type bits come from VNII Almaz in Moscow and the Institute for Superhard Materials (ISM) of the Academy of Science in Kiev, Ukraine. The two organizations have developed different technologies, but are closely linked. They have developed diamond-hard plates (WC and $\mathrm{Co}$ ) which are analogs of Western Stratapax cutters, and synthetic thermally stable polycrystalline cutters which are an analog of Syndax 3. ISM has also developed a special hard material called "Tveysal" which is produced by pressing.

Bits with cutters made of these materials are used for both oil and gas drilling, and for mining. Russian synthetic diamond bits are manufactured in sizes from $16.1-39 \mathrm{~cm}$ diameter $(6$ in - 15 in). In all, ISM has developed more than 30 types of full-face bits and about 26 types of core bits. More than $80 \%$ of the scientific drilling conducted by GNPP Nedra was done with bits using these materials.

Comparisons of the running characteristics of western Stratapax 2530 and Russian diamond-hard plates have been conducted. During typical tests, the cutters are tested by cutting an abrasive ring of various hardness and by planing sandstone of medium hardness. In a test, the wear after $1 \mathrm{~km}$ of cutting is estimated by measuring the width of the wear flat.

Komineft (a Russian company) tested drag bits of Russia and Belgium and obtained rates of penetration (ROPs) of $5 \mathrm{~m} / \mathrm{h}$ and $8.5 \mathrm{~m} / \mathrm{h}$ respectively over a $1000 \mathrm{~m}$ run. A Russian TSP bit designed with $60^{\circ}$ pointed cutters specifically for hard rock applications was tested against a roller cone bit in hard clays and medium and fine-grained sandstones. The TSP bit $(39.3 \mathrm{~cm}$ diameter) lasted $998 \mathrm{~m}$ at an ROP of $3.3 \mathrm{~m} / \mathrm{hr}$, the roller bit lasted only $90 \mathrm{~m}$ at the same penetration rate.

Downhole Motors (V. A. Shvetsky) - In contrast to US downhole motors, the Russians developed multi-lobe positive displacement motors (PDM) with low RPM. They now have available for use: general purpose motors (5.7 - 9.5 in. diameter), motors for workovers (2.1 - 5.0 in.), and motors for horizontal or directional work (3.5 - 6.75 in.). The motors for directional work are short (6.9 - $9.8 \mathrm{ft}$ ) for small-radius turns. They also have vane motors for coring (core diameters of 1.57 - $2.36 \mathrm{in}, 8-132 \mathrm{rpm}, 2284 \mathrm{ft} \cdot \mathrm{lbs}$ torque.) 
GNPP Nedra's research organization on motors is in Perm. Their Perm affiliate has developed a new type of motor called a cassette motor which is a combination of 3 or 4 motors placed in parallel connected to a common spindle (with a gear reduction). This enables the motor to have a very short length. The main advantage of the cassette motor is its short length for use in deviated wells. (The minimum radius is $98.4 \mathrm{ft}$.)

They have also developed a vane motor for coring which is a modification of a PDM. The section with bearings is a standard design, and the motor section is changed to provide systems with different diameters. The performance of the vane motor is similar to a PDM, but it is advantageous as it is more reliable at low speed (120-200 RPM). They have developed and tested a $95-\mathrm{mm}$ diameter motor. In test stand tests, the motor performed very close to theoretical with good reliability and serviceability.

Drilling Muds (Dr. E. Ya. Oxenoid) - GNPP Nedra has worked with many research organizations dealing with chemical additives for drilling muds:

- State Academy of Oil and Gas named after Gubkin; GNPP Nedra has close contact with scientists at this institute for exploration in oil and gas and for scientific drilling.

- VNIGNI Aprelevka; this company has worked with GNPP Nedra on solving the problems of drilling with heavy muds. (Mud density $2.0 \mathrm{~g} / \mathrm{cc}[16.7 \mathrm{lb} / \mathrm{gal}]$ and temperature $>200^{\circ} \mathrm{C}$.)

- UTA Industrial Institute; GNPP Nedra worked with them on muds for two wells exceeding 21,000 feet.

In support of their scientific drilling work, GNPP Nedra worked with several mud companies to develop muds for specific problems in which that company has expertise. They have specialized muds developed for:

1. Stable pressure gradient, stable rock, regions in Siberia, Western Siberia, and the Crimean. These are polymer-based muds, with or without bentonite, such as polymer-clay-potassium-based muds and clay-free muds. In addition, peat based muds are widely used for these areas as they are cheap and environmentally friendly. Peat-based clay and low-clay muds are widely used for lost circulation control, in permafrost, and in crystalline rock. Muds with fibers decrease the disintegration of clays, heal fractures, and decrease the effect of pressure pulses.

2. Abnormally high formation pressures with potentially unstable rock, regions in the North and South Caucasus, Ukraine, and some parts of Western Siberia.

3. Presence of salt rock with abnormally high temperature and pressure, regions in North Caucasus and the lower Volga. For these regions, salt-saturated drilling muds are used (gypsum potassium and alumina potassium.) However, GNPP Nedra had problems with these muds at high temperatures and when calcium or magnesium salts were encountered. Nedra then developed "Thermal-Plus 34 ". mud to combat these problems. It is stable at high temperatures: up to $220^{\circ} \mathrm{C}$ for pure drilling mud, and up to $182^{\circ} \mathrm{C}$ for mineralized mud (saturated with sodium chloride and potassium and magnesium chlorides). 
Cements (Y.M. Kurbanov) - More than $80 \%$ of wells in Russia are cemented with Portland cements. The state standard (GOST) is obligatory for all manufacturing companies and regulates the procedure for manufacture of pure and mineral-additive Portland cements. Cements covered under the GOST standards fall into three categories: 1) standard pure cement with less than 5\% gypsum and no other additives except clinker, 2) grouting cements with additives up to 20\%; and 3) cements for higher temperatures with additives up to 75\%, clinker-free material. Cements of type 1 and 2 are used for normal and intermediate temperature applications. At higher temperatures the third type of cement is used; its additives are for controlling density and temperature resistance and can be used at bottom-hole temperatures up to $220^{\circ} \mathrm{C}$.

Their standard analyses include spreading (tool developed at the Azerbaijan Institute of Oil and Chemistry), density (same as in US), time of setting (consistometer same as in US with a maximum temperature of $280^{\circ} \mathrm{C}$ ), strength (after setting), adhesion, permeability, and stability under different chemical conditions (for example in salt, $\mathrm{H}_{2} \mathrm{~S}$, and toxic materials). For research purposes, filtration properties including near-setting characteristics are measured. (They have patents for this test tool). Contraction properties are also measured for standard as well as expanding cements.

A cementing procedure is typically as follows: at the top of the well, special cements for very low temperatures are used. After the first intermediate casing standard cements (which vary according to the region) are used . In the Volga, standard Portland cement is used and cement/sand mixtures are used after $120^{\circ} \mathrm{C}$. In the lower Volga, $\mathrm{H}_{2} \mathrm{~S}$-resistant and salt-resistant cements must be used. In the Northern Caucuses, mineral-weighted, high-temperature cements are used. In central Russia, standard cements are used. Porous cements are used in sloughing sandstones where it is not effective to use mechanical filters for sand control.

In addition, the scientists at GNPP Nedra have developed a technology for making cements called "disintegration technology" which produces cements based on viscous materials of industrial waste. Using this technology, they have developed 30 cements; most of these cements are clinker-free. They have developed cements that are $\mathrm{H}_{2} \mathrm{~S}$-resistant and gypsum clay and Portland cements with mineral intensifiers. In addition, GNPP Nedra has developed cements for healing fractures (lost circulation) using rubber wastes; these lost circulation rubber cements are mineral-based, organic, and oil-based. They believe these elastic cements would be a good area for cooperation. They have also done work on cements for chemical waste (used in chemically aggressive media), and have information on cements for use in boreholes with very high pore pressures, expanding cements, and elastic cements.

Downhole Tools (O. A. Esipko) - The downhole tools available in Russia can be categorized into: tools for oil and gas, tools for production, and tools for core. Also, the tools can be separated into: tools for shallow wells $(<4 \mathrm{~km})$ with low temperature and pressure capabilities ( $\mathrm{T}<100^{\circ} \mathrm{C}$ and $\mathrm{P}<50 \mathrm{MPa}$ ); and tools for deep wells with severe temperature and pressure environments $\left(T \leq 200^{\circ} \mathrm{C}\right.$ and $\left.\mathrm{P} \leq 100-150 \mathrm{MPa}\right)$. In addition, there have been some prototype tools developed for the Kola super-deep well; these function to $250^{\circ} \mathrm{C}$ and $200 \mathrm{MPa}$. They were developed by the Scientific Institute of Geophysics.

Russian logging tools include tools for geophysical measurements and tools for measuring the condition of the borehole. Both simple (1 measurement) and complex (many measurements) tools are used. GERS in Tver manufactures the complex tools. Logging requires two runs for all the geophysical measurements and a third run for spectral gamma measurements.

There are approximately eight centers which develop and manufacture tools in Russia. These include: GERS in Tver, VNIGNI - Geophysics, VNIINefta Prom Geophysics, Geophys Prebore Ufa (oil and gas production well tools), and SKTBGeotron in Tumen (tools for wells up to $4.5 \mathrm{~km}$ deep.) 
Drill Rigs (Dr. E. Ya. Oxenoid) - By GOST standards, there are 12 classes or grades of rigs; these grades are based on hook loads and drilling depth (80 -1000 tons, $4100-52500 \mathrm{ft}$.) Dieselelectric rigs, classes 1-4, are manufactured in Volgagrad; classes 5-12 are built in a factory in Uralmash. Entire rigs are designed and manufactured at each place. Each rig is equipped differently, and parts are not standardized.

Drill Pipe (Dr. E. Ya, Oxenoid) - All drill pipe made in Russia is made to GOST standards and regulations. Their kellys are made to API standards, and have either square or hexagonal crosssections. The same factories that make the kellys also produce a wide range of drill collars. Nedra has done a comparison of GOST to API standards (up to API S-135) for drill pipes manufactured for the Kola well. They believe Russian drill pipe is reliable up to $5000 \mathrm{~m}$, but not deeper.

Because $90 \%$ of development drilling in Russia is done with downhole motors, they have developed aluminum alloy drill pipe. Aluminum drill pipe has many advantages over steel: it absorbs vibrations better than steel and is non-magnetic which is better for directional surveys. The most widely used aluminum pipe is Grade D (GOST) and is comparable to API G-55. They also have grades which are temperature resistant to $220^{\circ} \mathrm{C}$. The most durable grade is D16T, but it is only rated for moderate temperatures.

Standard aluminum drill pipe has steel tool joints. The dissimilar metals cause increased corrosion and wear. However, the scientists and engineers at GNPP Nedra developed a proprietary way to get around these problems when drilling the Kola well. With this method, there have been no breaks at the connection in the last 10 years. In addition, they have also produced aluminum pipe with aluminum threads.

There is currently a joint project among GNPP. Nedra, the University of South Carolina, Japan, and Germany to look at problems related to global change. They will be drilling into Baku Lake through ice to a $450-500 \mathrm{~m}$ water depth. They are using aluminum drill pipe as risers.

Blowout Equipment (V. A. Shyetsky) - The diameters and working.pressures of their blowout equipment are approximately the same as API standards. In Russia there are ten typical configurations for blowout equipment. The different configurations are categorized by the number of preventers, the number and location of bleed lines, the system of controls, the choke lines, the working pressure (2,000 - 15,000 psi), and the diameter (1 1/16 - $213 / 4$ inch.) Before 1992 blowout equipment was manufactured according to standards. Since then, they have been manufactured to technnical specifications. However, safety, testing, and inspections are governed by a code.

Roller Cone and Core Bits V.A. Shyetsky) - Roller cone bits are more common than drag bits. Approximately $90 \%$ of drilling is done with cone bits. Typically, roller cone bits have unsealed bearings, however, they have more recently been made with sealed bearings. Roller cone bits are classified by the number of cones, type of teeth (shape, inclination, angle), type of bearing (roller or ball), and the flushing type (nozzle or port).

Both synthetic and natural diamond bits are used for coring. The Institute of Superhard Materials in Kiev makes drill bits and core bits with superhard materials for the teeth. In addition, prototype bits with sealed bearings and small diameters have been developed and tested in the mechanical laboratory of VNIIBT. ROP and life of these prototype bits are several times higher than typical. These are experimental bits that have been produced and tested and are much better than typical Russian-manufactured bits. According to Russian researchers; some of these bits are comparable in performance to western bits. 
Super-Deep Drilling (Dr. E. Ya. Oxenoid) - GNPP Nedra has been involved with drilling the Timano-Pechora, Kola, Tumen, and Ural super-deep wells. The Ural well was drilled with 2 turbines and 2 bits which were next to each other in the hole; each bit rotated, and the overall drillstring rotated causing the bits to move in a circular direction, thus creating a round hole. Each turbine turned at approximately $100 \mathrm{rpm}$, and the drill string turned at approximately 10 rpm. This method was used to drill the large diameter well and prevent wellbore deviation. They have had extensive experience with the breakouts and deformation due to stresses and have methods for dealing with these problems.

Environmental Problems (Dr. E. Ya. Oxenoid) - There are a large number of regulations that must be followed in order to get a permit to drill a well in Russia. For example, there are 10 documents covering requirements of a general nature, 12 documents on regulations related to soil, 8 on the interior of the earth, 22 on surface and ground water, 7 on wildlife, and 13 on the atmosphere. To conduct a drilling operation, a company must coordinate with seven different organizations in Russia. An ecology plan must be filed, and a permit or license must be obtained. GNPP Nedra can provide information on these requirements and help getting through the system.

\section{State Oil and Gas Academy Named after Gubkin}

At the State Oil and Gas Academy Named after Gubkin in Moscow, Russia, we met with several geophysicists and geologists, including: Adam Urupov, Victor Yermolkin, Miron Rapoport, and Valery Dobrynin. We discussed oil- and gas-related research, oil prospecting, and exploration in particular.

Surface Geophysics (Dr. Miron Rapoport) - Dr. Miron Rapoport is the Chair of Surface Geophysics. His work is in seismic prospecting for oil and gas. He has experience with vertical seismic imaging in many areas $3-4 \mathrm{~km}$ deep, but not in regions below salt domes. He is very interested in cooperation.

Seismic Research (Dr. Adam Unupov) - Dr. Urupov has experience with seismic anisotropy. He discussed various types of source/receiver placements, frequencies, mathematical models, identification of fractures, determination of fluid saturation, and identification of the orientation and density of cracks while drilling.

Borehole Geophysics (Dr. Valery Dobrynin and Prof. Wieldenschten) - The Borehole Geophysics department, of which Dr. Valery Dobrynin is head, was established in 1951 and was the first in the USSR. Dr. Dobrynin discussed the detection of various fractures in some detail. Prof. Wieldenschten works on induced polarization, telemetry, nuclear geophysics, etc. Their lab is not oriented toward interpretation of data. Their borehole geophysics technology was used in the Tangez oil field which has an oil bearing thickness of $1 \mathrm{~km}$ and is a low porosity, dense matrix with producing fractures. One of the techniques used is to dissolve a radioactive tracer in the drilling mud, then log with a gamma tool. They also use broad-range acoustic logging; P, S, and standing waves are used for determination of strength and elasticity in rocks.

Geology (Professor Victor Yermolkin) - Dr. Yermolkin chairs the department in charge of geology for prospecting and exploration. This involves exploring for new deposits and estimating the potential for reserves. Their department was in charge of exploration geology for all of the former USSR territories. 


\section{All-Union Scientific Research Drilling Technologies Institute (VNIIBT)}

At VNIIBT, we met with several scientists and engineers and discussed drilling techniques and equipment. While there, we met with Boris Kurochkin, Dmitre Baldenko, Aleksey Messer, Mr. Litvyak, Alexander Saroykin, Vladimir Brajyentsev, Yuri Tsyrin, Leo Faroukshin, Alexander Mnatsakanov, and Nina Sukmanova. We were given a catalog detailing their available technologies. The catalog includes roller cone bits, diamond bits, core bits, core turbodrills, core catchers, reamers, hole openers, packers, fishing devices, turbodrills, and junk baskets.

VNIIBT was funded by the Ministry of Oil and Gas in the former Soviet days. Their purpose is to use scientific experiments and testing to develop drilling techniques. They develop new designs and techniques, and produce new equipment in a prototype scale. Before perestroika there were 3000 people in Moscow and 3000 people in Perm, with 3 plants and an experimental testing center. They have a unique test stand in Perm with a depth of $50 \mathrm{~m}$ and a maximum experiment temperature of $180^{\circ} \mathrm{C}$. A test rock is placed at the bottom, and drilling tests can be conducted for $1 \mathrm{~m}$ of drilling with a load of $400 \mathrm{kN}$ and flow rate of $1-20 \mathrm{~V} / \mathrm{sec}$. They also have motor test stands at their facility just outside of Moscow where they can test full-scale drilling equipment, bearings, and drilling muds. They also used the test stands to evaluate water jet drilling 25 years ago. Since perestroika they are down to 400 specialists and are no longer financed centrally; only $10 \%$ of their funding comes from the state.

VNIIBT has three large groups of laboratories and departments:

1) Motors - designers and developers of downhole motors using the test stands. Developed turbodrills, which are used in $80 \%$ of all Russian drilling.

2) Bits, reamers, hole openers, diamond tools - including cutters, tricone bits, core bits, core catchers, and breakers. In Sumara, a plant was built in conjunction with Dresser for making "world-class" bits. They also make such bits at VNIIBT on a smạller scale.

3) Packers and other equipment - including packers that allow them to cement step-by-step and modular packers to assemble to any length. This allows them to selectively choose intervals with packers. They have packers to control lost circulation, packers for pressure testing casing, and packers for workovers. They have casing window cutters for sidetrack drilling. They build stabilizers and safety subs, as well as a hydro-mechanical tool for recovering a packer from a well or for releasing stuck drill string. The hydro-mechanical tool produces impacts for unsticking on the order of $5000 \mathrm{kN}$. Bowen in the US makes a tool for the same purpose, but it is very different. Also, they have developed (along with the Moscow Energy Institute) a magnetic junk basket. They have also done some development of drilling muds and have done research on the melting of rock for stabilization.

Vane Motors (Dmitre Baldenko) - Since 1965, the US and USSR has had simultaneous development of new hydraulic downhole motors; in the US it was. Smith International and Dynadrill: in the USSR it was VNIIBT and its affiliate in Perm. Early on, the Russian concept was to develop a high-speed, low-torque motor as an alternative to rotary drilling. A patent for a multi-lobed motor was granted in 1965, and a prototype was tested in 1969. In 1969-75 testing and development of the multi-lobed motor continued. Ten patents on the geometry of the working and main parts were granted during that time. In 1975 they began to produce vane motors on an industrial scale. To date, $\mathbf{3 0}$ million meters have been drilled with these motors ( $80 \%$ of total drilling). Typically, top intervals (up to $600-700 \mathrm{~m}$ ) are drilled with turbines, and 
deeper.intervals are drilled with vane motors. Penetration rate is lower with vane motors, but the bit life is twice as long. The vane motors are manufactured (3000-4000 annually) in a variety of diameters (54-240 $\mathrm{mm}$ ); they also manufacture vane motors for workovers (54-127 $\mathrm{mm}$ ). In 1981-83 they sold the license to Drilex. The design of Drilex motors is not very different than what they make at VNIIBT. Later, they developed second-generation motors with optimized energy parameters.

VNIIBT has recently developed a new series of motors for horizontal drilling (DG Series). These motors have a stationary stator and a planetary rotor. They have a very small spindle, but have standard-size moving parts. They have different types of motors for directional and horizontal drilling.

\begin{tabular}{|c|c|c|}
\hline DG-60 & $60 \mathrm{~mm}$ diameter & (sold to Norway) \\
\hline DG-95 & $95 \mathrm{~mm}$ diameter & (used to drill side tracks and horizontal \\
\hline DG-108 & $108 \mathrm{~mm}$ diameter & intervals in previously cased wells) \\
\hline DG-155 & $155 \mathrm{~mm}$ diameter & (meant for drilling new horizontal wells) \\
\hline
\end{tabular}

The length of the DG-95 motor is only $2.64 \mathrm{~m}$. The working torque on the biggest motor (DG108) is approximately $1000 \mathrm{~N} \cdot \mathrm{m}$ which is a high torque for a motor this size. Working speed of the motor is approximately $200 \mathrm{rpm}$.

Their current area of research is using computers to control the mud pump speed and, therefore, the speed of the motor and the bit. Their plan is to measure flow rate and pressure and use them as indicators of motor performance, then use a computer to control motor parameters. They are looking for parties interested in funding or becoming involved in this research.

Turbines (Mr. Litvyak) - Their lab has been in charge of development of high speed turbines (300-600 $\mathrm{mm})$. They have turbines available ranging from $105-240 \mathrm{~mm}$ in diameter: Their turbines are built with a plastic stator to be flexible, so they are not for high temperature $\left(T \leq 120^{\circ} \mathrm{C}\right)$. Their turbines produce a torque similar to Westem turbines, however, if no special regulator is used, they can produce 1.5 times higher torque. The Kola super-deep well was drilled with their turbines using a gear reduction (from $200 \mathrm{rpm}$ to $40 \mathrm{rpm}$ ) and a steel stator for higher temperature capability (TS250 $0^{\circ} \mathrm{C}$ ). This reduction gear was also developed at VNIIBT.

Coring (Alexander Sarovkin) - Their lab is the only place in the country where they develop coring tools; all other manufacturers use their designs. They develop and use mostly cone core bits, with several different types ranging from 4 to 8 cones. They are currently working with the Ocean Drilling Program to supply core bits and coring equipment for Norway and Gibraltar. Their designs are different from Eastman Christensen coring tools. For example, their regulating head is at the top of the core-catcher. Their core barrel can be equipped with centralizers. They have reportedly developed quality equipment but are much cheaper than Western technology. They have an $88 \%$ average core recovery with an 8 cone bit. They also have equipment for horizontal coring. These are for kickoffs from vertical wells; the equipment has articulated joints for a $120.6 \mathrm{~mm}$ diameter hole (40 mm diameter core) with a $20-30 \mathrm{~m}$ radius of curvature.

Reamers. Hole Openers, and Other (Alexander Saroykin) - The reamers and hole openers developed in this lab are specifically for turbine drilling. They have also developed a centralizer design which can be installed on any part of the turbine. They have also developed a method for predicting inclination angle. Recently, they have begun working on developing stabilizers for rotary drilling. They have compared their stabilizers with those of SMF Int. and believe theirs are better. The hole openers developed in this lab are special assemblies for step-by-step drilling. 
For example, several wells in Kazakhstan were drilled with a $295.3 \mathrm{~mm}$ pilot bit and a $393 \mathrm{~mm}$ diameter hole opener. This method produced a higher ROP and a better quality borehole. A recent blowout in the Tangez field was remediated by drilling two horizontal wells with their equipment.

Cone Bits (Vladimir Braiventsev) - Over the past 30 years, they have developed low-speed cone bits similar to Western bits, high-speed $(300 \mathrm{rpm})$ bits for turbine drilling, and cone bits for mining hard rock. Approximately $70 \%$ of turbine drilling in Russia is performed with high speed cone bits, $23 \%$ with low speed cone bits, and the remainder with diamond bits. They have three labs: a design lab, a metals and materials lab, and a technical specifications lab. Previously, they developed the standards, including ISO standards, and then these standards and designs for bits were transferred to factories for manufacture.

The level of development of high-speed bits in Russia is reportedly higher than that of Western bits. The latest comparison with Western bits was in 1990-91. Reed compared their bits with the bits of this lab for drilling in western Siberia. These were both insert and milled tooth bits with an 8.5 in diameter. Their bit was designed for soft, abrasive rock and had unsealed bearings (Code III 815). During the field test of the insert bits, the Reed bit reportedly provided 2.5 times lower service life and 1.5 times lower ROP than the Russian bit. During the field test of the milled tooth bits, the Reed bit demonstrated 2 times lower life with a comparable ROP. They do admit that for low speed drilling, American bits are better; but they maintain that for high speed drilling, their bits are better. During a field test comparing their bits to Smith and Hughes bits at low speeds (turbines with gear reduction, 120-140 $\mathrm{mpm}$ ), the Russian bits provided 2-3 times higher ROP but 10 times lower life. In other tests (rotary drilling and vane motor drilling) Russian bits have been comparable to Western bits.

Brajyentsev believes that American bits are better for drilling hard rock simply because America has better hard alloys. However, Russia now has new hard-alloy technology, developed by the All-Russian Institute of Superhard Materials, which may bring them to the same level.

They would like to develop a high-speed turbine bit with sealed bearings. With such a bit, the range of application of turbine drilling would be larger.

Packers (Yuri Tsyrin and Leo Faroukshin) - This group provides both research and development of packers and their use. They have casing packers which are hydraulically controlled and not redrilled, and cementing packers for step-by-step cementing and packers for open-hole cementing. We were given handouts which discuss several different types of packers developed at VNIIBT.

The PDM and PDM-1 models are hydraulic packers for step-by-step cementing. The packers use hydraulic or mechanical expansion, depending on the type. Mechanical packers are used for intermediate casing, and hydraulic packers. are used for open-hole casing. A packer inflation diameter change of 1.4-1.5 times is typical. For cementing with lost circulation, the packer is placed above the loss zone in a first stage cement, a second plug is dropped for the second interval, and then cement is pumped above the packer. The entire plug is then drilled through. Typical packers can operate up to $150^{\circ} \mathrm{C}$, but different materials can be used for higher temperatures. These packers have been used to depths of 5000-6000 m. Interest in these packers is growing because they can be used in horizontal drilling.

-PGPM packers can be placed at any interval to separate formations. Results shown for eight different wells showed that the amount of produced water was significantly reduced with the use of these packers. These wells had very closely spaced producing regions, side-wall caving, and abnormally high pressures. There can be up to four packers in one casing. 
VNIIBT has also developed new technology for stage cementing. This new technology does not require drilling anything from the well after cementing. It uses a special polymer cement to selectively plug certain intervals. Injection is performed by placing a plug into the casing that opens and closes a window in the casing.

Solving Drilling Problems (Boris Kurochkin) - They have many methods of dealing with lost circulation problems. They determine the parameters of the lost circulation zone by measuring pressure downstream of the pump. The intensity of loss zones they encounter varies from 1-120 $\mathrm{m}^{3} / \mathrm{hr}$ loss of drilling mud. Sometimes, they use a straddle packer to isolate and evaluate lost circulation zones, and use special packers to treat the zones.

They have also solved lost circulation problems using American thixotropic cements: As a possible joint project, they could evaluate these cements and sites for testing. They have two compositions of Latex: one that is frost resistant to $-60^{\circ} \mathrm{C}$ (recent development) and another that turns to rubber at temperatures exceeding $80^{\circ} \mathrm{C}$ (a thermal setting latex powder mixed with oil at the site.) Ordinary latex solidifies with contact with salt water at any temperature. They also have some natural rubber compounds that are manufactured using vacuum disintegration technology. These compounds solidify after approximately 12 hours.

They have a unique tool with brushes and nozzles that was developed and is used only in Russia; the brushes remove mud cake, and the nozzles inject plugging materials. This tool works only in a round borehole in good condition. For intense lost circulation, they have a device which injects a large amount of lost circulation material at the wellhead for increased concentration in the lost circulation zone.

They also have anti-sticking glass balls used to provide drillstring lubrication in horizontal drilling. Although such balls are also used in the US, they reportedly have a special way to manufacture these balls in Russia. In addition, they are now testing mechanical centralizers for casing.

\section{VNIGNI}

We met with one branch of VNIGNI in Aprelevka, Russia (Moscow Region). The scientists at this location deal with research and development of drilling muds. We met with Ivan Timokhin, Victor Teslenko, Anatoly Rusaev, Marina Afanasieva, Claudiana Sukova, and Dr. Ogalykhen.

The main branch of VNIGNI is in Moscow and consists mainly of geologists working in oil and gas exploration. This department, founded 20 years ago, is just outside of Moscow and deals with drilling muds. They have 80 people and formulate different types of muds for different drilling problems. They also have an on-site drill rig for testing new drilling muds and a core storage facility which houses $75000 \mathrm{~m}$ of core from oil and gas wells. They have equipment to produce additives on a large scale, but can only produce soluble cellulose (CMC) on a small scale. They also have equipment for testing lost circulation materials and filtration.

They are interested in cooperative projects: development of devices, $\mathrm{H}_{2} \mathrm{~S}$ problems, super-heavy drilling muds, and thermal- and salt-resistant (CMC-based) muds. They believe they are the best institute in Russia on CMC development and different modifications of CMC. 
Mud Additives (Dr. Timokhin) - They have developed chemical additives, thermal and salt resistant agents to stabilize water-based muds. Most of these additives are dissolvable cellulose (CMC), but they have also done lab tests with other additives. Typical CMC is stable to $140^{\circ} \mathrm{C}$, however, they have determined inhibitors of destruction and can produce CMC muds stable to $200^{\circ} \mathrm{C}$. Their latest development is a CMC material of grade 700 with a level of polymerization up to Grade 1000 (CMC-700). Modifications of CMC which are ecologically acceptable have been used to drill the deep and super-deep wells with high salt aggression and bottom hole temperatures of $203^{\circ} \mathrm{C}$. They have developed CMC muds which resist chemical aggression $(\mathrm{NaCl}, \mathrm{CaCl}, \mathrm{MgCl})$ at high temperatures. This cellulose formulation in combination with their inhibitor of destruction and foam inhibitor have been used in deep wells. CMHEC is their thermal-resistant composition. One foreign company produces it widely, and it has been used in the Caspian and the Tumen basins. They have the ability to develop a small amount of new material for laboratory tests, then produce a large amount for large-scale tests. They also produce other additives such as viscosifiers and thinners. They produce mixtures of additives at their lab and send them to their customers. Thermal-resistant CMC would be an ecologically safe drilling mud for geothermal drilling.

$\mathrm{H}_{2} \mathrm{~S}$ and $\mathrm{CO}_{2}$ Detection and Corrosion (Dr. Sukova) - They have a new lab which deals with problems associated with $\mathrm{H}_{2} \mathrm{~S}$ and $\mathrm{CO}_{2}$ corrosion. They have developed a device for diagnosing the inflow of these acidic gases into the borehole. They have developed additives which form an irreversible bond with $\mathrm{CO}_{2}$ and $\mathrm{H}_{2} \mathrm{~S}$ under different temperatures. They have also developed additives which are corrosion inhibitors. The US company, Mud Duck, developed a method for detecting $\mathrm{H}_{2} \mathrm{~S}$ in mud. VNIGNI developed and tested a similar device; however, they discovered that detecting the time at which the $\mathrm{H}_{2} \mathrm{~S}$ has saturated the mud is too late. They, therefore, began to develop techniques for detecting the gases when they first enter the well (before saturation.) They developed additives that absorb $\mathrm{H}_{2} \mathrm{~S}$ and a device the measures the amount of this additive. They can thus measure the $\mathrm{H}_{2} \mathrm{~S}$ absorption of the mud and detect $\mathrm{H}_{2} \mathrm{~S}$ well before it is saturated. They also can detect $\mathrm{CO}_{2}$ using the same technique.

They have also worked with ferrous materials, studying the kinematics of $\mathrm{H}_{2} \mathrm{~S}$ absorption. They have determined the rate of absorption of $\mathrm{H}_{2} \mathrm{~S}$ as a function of time, temperature, and metal composition. They have developed ferrous absorbers and organic mineral absorbers. The organic mineral absorbers (MFK) are ecologically safe. They have also developed other organic additives which behave like MFK. They have developed drilling muds to slow the reaction of steel to $\mathrm{H}_{2} \mathrm{~S}$ and protect the drilling equipment. These muds have inhibitors which absorb $\mathrm{H}_{2} \mathrm{~S}$ and inhibit corrosion. They also have additives that protect under $\mathrm{HCl}$ aggression. All of these developments are widely used.

Grouting Mixtures and Oil-Based Muds (Dr, Ogalykhen) - One of their main areas of research is in heavy-weight oil-based muds with a density up to $2.6 \mathrm{~g} / \mathrm{cc}$, using barite with a density of 4.2 $\mathrm{g} / \mathrm{cc}$. Foreign mud systems use lead sulfate with a density of $7.5 \mathrm{~g} / \mathrm{cc}$. Their heavy-weight oil muds have been used in wells with very high pressure gradients These muds helped to penetrate a salt formation with a high pressure gradient, and have been used to help stabilize clay and shale. In addition, they have also developed super-dense packer fluids (oil-based) with a density up to $2.9 \mathrm{~g} / \mathrm{cc}$. These are used for emergency killing of a well with both water-based and nonwater-based muds.

They have developed special washing fluids to increase cement/borehole bonds. This is used in wells with oil-based mud. They have developed oil-based slurries which maintain the permeability of the reservoir. The emulsion is based on Portland cement and does not filtrate water into the formation. 
They also have devices and technologies to measure very low-temperature properties of drilling muds. These have been used to develop additives to prevent freezing in oil-based muds. They have also produced additives to increase the destruction of the rock. They have nonstandard high-pressure equipment to measure stability of the rock when clay based muds are used.

They also have developed methods and recommendations on how to use their muds and additives while drilling exploration wells, especially for non-invasive coring. These muds and techniques increase the accuracy of estimation by $10-15 \%$ when using core analysis for oil and gas exploration.

Their muds have been used to drill super-deep wells with very high pressure gradients in Kazakhstan, Ukdon, Archangelsk, and Tumeni-Pechor province. They have also developed additives for drilling through clays and shales. These additives, which contain oil, plug cracks, decrease rate of watering of rock, and increase borehole stability time.

They have anti-sticking additives which prevent clay sticking on pipes and bits. They have lab equipment that simulates the sticking of pipe in clay cake. This allows them to measure the strength of the mud cake. They have tested clay-based muds by simulating the in situ pressure and temperature of rock. They also have special equipment for measuring bulging effects used to develop additives that prevent clay swelling.

\section{VNIIgeosystem}

At VNIIgeosystem in Moscow, Russia, we met with Dr. Michael Khoziainov, Dr. Eugenia Cheremisina, Dr. Notekoyeu, Dr. Vorozhbitov, Dr. Valery Ruchnov, and Dr. Suliko Chutkerashvili.

In the Soviet days, this group belonged to the Ministry of Geology and Academy of Science. They deal mostly in geophysical research, especially fundamentals, such as the deformed stress state of the earth and applied geophysics (e.g., seismic exploration for oil and gas). They also have a laboratory for drilling research and have dealt with some of the problems related to the Kola well. They have a geochemistry lab and also deal with nuclear geophysics and develop nuclear tools for borehole geophysics. They have a Geodata laboratory where they develop geographic information systems with an integrated interpretation of geophysical data obtained from space, above ground, and below ground. In addition, they deal with ecological problems related to geology. They employ over 500 people. They anticipate designation as a State Lab in October 1994 and will then be financed by the State.

Geoinformation Laboratory (Dr. Cheremisina) - In this lab they develop universal technologies integrating geology, ecology, and modeling of processes. They develop computer technology and electronic mapping using and integrating all levels of information (underground, surface, and space). There is an international system called ARCINFO, but they found it difficult to use, so they developed their own system. The information is used to construct cities, protect the environment, mine for coal, mine for mineral resources, and other systems. They have developed special technologies for interpretation of data which allows the specialist to control the analysis. They use a variety of analyses, including potential field, geophysical modeling (direct and indirect), and statistical. They have developed computer graphics for visualization of the data and analysis. This technology has applications in a wide variety of problems. Thirtyfive specialists (technologists, programmers, mapping specialists, and computer graphics experts) work in the lab; the average age is $28-29$ years old. This is of interest as the average age of Russian scientists is much older than this. 
Drilling Technologies (Dr. Vorozhbitov) - Dr. Vorozhbitov is head of the lab for ultra-deep drilling. They provide the general design of the deep and super-deep wells. They developed the specifications for drill rigs for super-deep drilling (Uralmash 15000), for thermal resistant reduction gear turbines, and for aluminum drill pipe for super-deep drilling. In 1984 GNPP Nedra took over drilling of super-deep wells; Nedra is in charge of wells to $15 \mathrm{~km}$, this lab is in charge of $20-25 \mathrm{~km}$ (future) wells.

Dr. Notekoyeu works in a lab where they provide a comprehensive investigation (geachemical, geophysical, thermal, etc.) of super-deep wells. His lab produced the book entitled "Kola Super-Deep Well" by Springer Publications, which includes their study of that well. They have obtained information on the Berta Rogers well in the US, as well as on the Salton Sea wells, the Siljan well in Sweden, and other high-temperature wells in England. They have studied these wells and compared them to wells in Russia based on their geochemistry and geophysical borehole investigations. They have used this information to study the geochemical character of flow in the earth.

Dr. Notekoyeu is interested in developing instruments that can be left downhole for gas detection over extended periods of time.

Geochemical Instrumentation and Metrology (Dr. Valery Ruchnov) - In this lab they develop theories and chemical models for oil and gas exploration. These models of prediction are to understand processes of, for example, how oil is formed or how coal is deposited. These models are used to specify the type, necessary accuracy, and location of measurements that need to be made for the prediction. For example, he has studied gases in rock and in boreholes. Gases absorbed in rock are important because they show how the earth "breathes" which can indicate stress deformations in the rock that determine the oil-bearing capacity of the rock. They have developed a technique which recovers absorbed gases from the near-surface rocks and have developed a model based on these measurements. There is instrumentation on site to measure hydrocarbon elements and to measure absorbed gases in cuttings. Their system is reportedly competitive with Rockwell software: They have also studied the gases of deep wells. They did a study of 28 wells in Eastern Siberia and modeled the gas fields. They also use this technology to model coal beds. This subsoil near-surface sampling can be used to create a map of the nearsurface gas fields. It can also be used to place sensors for seismic studies. Deep drilling and seismic work have been done and prove the conclusions of their near-surface measurements. This method could also be used for ecological problems.

Geoecological Lab (Dr. Suliko Chutkerashvili) - In the geoecological lab they deal with all fluids under geological investigation in Russia. They use advanced technologies to evaluate the geoecological state of global, regional, and local areas. The lab has been doing this work for 30 years. They use field work, analysis, and monitoring to determine geological, geochemical, and geophysical data and then make ecological maps using computers. They also do radiological and radon studies.

\section{St. Petersburg Mining Institute}

- In St. Petersburg, we met with Yuriy Dyadkin, Vladimir Litvinenko, and Vladimir Klimov to discuss work being conducted at their institute, not only in drilling but in geothermal research as well. The St. Petersburg Minirg Institute (SPMI) works very closely with the Institute of Drilling in St. Petersburg. They deal with drilling muds, high-temperature logging, lost circulation materials, rock melting, foam cooling of boreholes for logging tool runs, and diamond drilling. They have contracts with DBS and Longyear, and have had close contacts 
with Los Alamos National Laboratory on rock melting. In June 1995, they will host a seminar on drilling under complex conditions. Geothermal drilling will be included in this seminar.

Geothermal Technology (Prof. Yuriy Dyadkin) - Professor Dyadkin's work deals with ways of extracting energy from rock. The work at St. Petersburg Mining Institute has been to create an artificial reservoir by hydrofracturing. The Hot Dry Rock (HDR) work at Los Alamos has demonstrated the technical possibility of creating a heat exchange surface, but it has not demonstrated adequate flow capability; the impedance (pressure drop) of their fracture system is too high to be viable. SPMI is now working on ways to lower the impedance of the fracture/heat exchange system by using controlled, directional hydrofracturing. Dr. Dyadkin has done experiments with GNPP Nedra at a depth of $3.7-4 \mathrm{~km}$ and a temperature greater than $200^{\circ} \mathrm{C}$. Although they were able to control the direction of the fractures, short-circuiting of the flow caused a low energy output. Therefore, it is necessary to improve the theory of fracturing. He is currently working on hydrofracturing experiments, developing circulation systems and optimizing the circulation systems using computer models. In his current work, he is using hydrofracturing to create the fractures but is using other technologies to treat them. Geothermal hydrofracturing is very different from oil and gas hydrofracturing. He has studied hydrofracturing by gas dynamics (pyrotechnics), cryogenics (expanding fractures by freezing water), and small charge blasting.

Another idea of Dyadkin's is geothermal/coal technology or the underground combustion of coal. In this technology, a coal seam would be hydrofractured and the coal combusted to create a high-temperature reservoir for geothermal fluids.

Foam Drilling (Vladimir Klimov) - They have done research on diamond coring with foam to clean and cool the bit. They use foams because of lost circulation problems. Usually there is 3 parts air to 1 part water and other additives. The deepest well they have cored in this manner (with foam) is $2000 \mathrm{~m}$. They have developed a special booster to increase the pressure of the air by $40-60 \mathrm{~atm}$, allowing the use of small compressors $\left(2.5 \mathrm{~m}^{3} / \mathrm{min}\right.$, with about $1 \mathrm{~m}^{3} / \mathrm{min}$ going to drilling) and small pumps $(10-20 \mathrm{l} / \mathrm{min})$ for the liquid part of the system. They have a special design for foam core bits. They use this design and models of bit temperature to optimize bit weight and rpm. This foam system does not work with wireline coring because the annulus is too small and the pressure drop is too high. They perform foam destruction using a patented aerodynamic radial flow injector combined with heat. This equipment was developed by SPMI and the All-Union Drilling Institute in St. Petersburg. They also have a computer model of this foam drilling system. Pressures and temperatures predicted by the model are within $10 \%$ of field and laboratory experiments. Thus far the holes they have drilled with the foam system are typically 59 - $93 \mathrm{~mm}$ diameter, but they have drilled holes as large as $132 \mathrm{~mm}$.

Quick Setting Cements (Vladimir Klimov) - They have also done some work on emplacing quick setting cements for lost circulation control. They first tried putting the cement in bags in the borehole, drilling through the bag, and then pressing the cement into the fractures. This did not work very well as the bag got in the way. They next tried putting the cement into the borehole in tablet form. They drilled through it, which activated the cement, and then pressed the cement into the borehole. This method worked better, but they have not had the opportunity (funding) to continue this work.

\section{VNIIgeofizika Neftegeofizika}

Neftegeofizika is located in Moscow and has been conducting geophysical studies for the exploration and production of oil and gas for over 50 years. Discussions have been held with the 
institute's director, Dr. Alexey Mikhaltsev, and Dr. Alexander G. Budagov, Professor Oleg A. Potapov, and Dr. Leonid Brodov.

The institute is actively involved in all areas of petroleum-related geophysics. A major effort is in the area of basin modeling and reservoir characterization. They have developed the COMPAC-GEOCOMPASS system, which is a numerical basin model. It is based on a variety of mathematical models for prediction and pattern recognition. The information base for their numerical model is a database management system called DBMS GEOCOMPASS. This database includes geological, petrophysical, well-logging, and geophysical data from oil and gas fields in different areas of Russia, including Western Siberia, Eastern Siberia, and TimanoPechorskaya.

In the area of seismic exploration, Dr. Brodov and his associates have made significant progress in developing theoretical links between seismic anisotropy, fracturing, and fluid flow. They have developed novel inversion techniques of multicomponent seismic data that may allow improved detection of subsurface fractures. These techniques would be an important development for characterizing a reservoir's natural fracture system and could have direct application to predicting fluid flow behavior in an oil reservoir. A thrust-one project has been funded by the USIC to develop a research program with Dr. Brodov on seismic anisotopy.

\section{POSSIBLE AREAS FOR COLLABORATION}

All of the scientists and engineers with whom we visited were very interested in any kind of collaborative research work. Certainly, there are areas of interest and/or expertise within each company that were not discussed at our meetings. The particular areas of possible joint research discussed during our meetings are highlighted below.

The scientists and engineers at GNPP Nedra are interested in performing joint research and development in the areas of core analysis, cements using the disintegrater technology, light aluminum alloy pipes, borehole geophysics (logging), and their downhole cassette motor.

At the State Oil and Gas Academy Named after Gubkin, the researchers are interested in furthering their work in oil and gas seismic prospecting; and identification of fractures while drilling using seismic techniques.

Engineers at the All-Union Scientific Research Drilling Technologies Institute (VNIIBT) are interested in continuing the development of downhole motors, gear reductions for turbines, high-speed roller cone bits with sealed bearings, and novel cementing applications using thixotropic cements.

The possible areas of cooperation discussed at the Aprelevka branch of VNIGNI include development of new additives and devices for testing these additives, developing means to overcome $\mathrm{H}_{2} \mathrm{~S}$ corrosion problems, and heavy-weight drilling muds.

Areas in which the people at VNIIgeosystem are working are detailed above. Areas for possible joint collaboration were not discussed.

At the St. Petersburg Mining Institute, they are interested in collaborative work dealing with hydrofracturing for geothermal systems, foam coring, and quick-setting cementing. In addition, they are looking for partners in a geothermal project for the city of St. Petersburg. 
Appendix A

ADDRESSES OF VISITEDD INSTITUTES

$-16-$ 


\section{Appendix A - ADDRESSES OF VISITED INSTITUTES}

GNPP Nedra

Svoboda, $8 / 38$

Yaroslavl

150000 , Russia

Fax: 0852-32-84-71

E-mail: postmaster@nedra.yaroslavl.su

Dr. Bilal N. Khakhaev

Director General

Ph: 0852-22-23-01

Oleg A. Esipko

Ph: 0852-11-73-32

Alexander Borisenko

Senior Consultant

Foreign Economic Relations Division

Ph: 0852 32-89-69
Dr. Lev. A Pevzner Deputy Director General Ph: 0852-32-83-88

Dr. Yaragui M. Kurbanov Chief of Research Laboratory for Viscous Materials and Well Cementing Ph: 0852-23-56-44

Vladilen A. Shvetsky

Deputy Head

Bureau of Design and Technology

Ph: 32-89-66

State Oil and Gas Academy named after Gubkin

Lenin Avenue, 65

117917, Moscow, Russia

Professor Victor I Yermolkin

Ph: 135-79-76

Professor Miron B. Rapoport

Fax: 135-85-06

Ph: (095) 135-84-16

Valery M. Dobrynin

Chairman and Professor

Prof. Adam Urupov

Well Logging Department

$\mathrm{Ph}$ : 135-70-26

$\mathrm{Ph}: 135-70-56$

All-Russian Drilling Techniques Research Institute (VNIIBT)

6, Leninsky Prospect

Moscow, 117957, Russia

Alexander V. Mnatsakanov

General Director

$\mathrm{Ph}: 236-1186$ and $236-0170$

Fax: 236-2071 and 230-2945
Aleksey G. Messer

Deputy Director

$\mathrm{Ph}: 236-2055$ and 236-1186

Fax: 236-2071 and 2302945 
Appendix A - continued

All-Russian Drilling Techniques Research Institute (VNUBT) - continued

Dr. Yuri A. Tsyrin

Head of Laboratory

$\mathrm{Ph}:$ 235-9124

Vladimir Brajyentsev

Ph: 554-6492

Nina A. Sukmanova

Research Worker

$\mathrm{Ph}: 236-1186$
Leo H. Faroukshin

Scientific Worker

Ph: 236-1186

Dmitre F. Baldenko

Head of Laboratory

Ph: 236-1186

\section{Aprelevka Branch of VNIGNI}

1, Ketritsa str.

Naro-Fominsk District

Moscow Region

Aprelevka, 143360

Russia

Dr. Anatoly A. Rusaev

Director of Aprelevka Branch of VNIGNI

Ph: (095) 436-51:43

Dr. Marina S. Afanasieva

Chief of Department of Geology

Ph: (095) 436-51-43

Fax: 07 (095) 292-65-11 Nedra box 359

Dr. Ivan M. Timokhin

Head of Department

Ph: 436-50-97

Victor N. Teslenko

Head of Laboratory

Ph: 436-50-97

VNIIgeosystem

8, Varshavskoe

Moscow, 113105, Russia

Dr. Michael Khoziainov

Deputy Director

Ph: (095) 954-51-31

Fax: (095)958-37-11

e-mail: ROOT@GEOSYS.MSK.SU

Dr. Marat I Vorozhbitov

Head of Laboratory for

Ultra-Deep Drilling Development

$\mathrm{Ph}: 234-53-50$

Dr. Suliko E. Chutkerashvili

Head of Gececological Laboratory

Ph: 952-26-25

Fax: (095) 958-37-11

Fax: (095) 230-37-11

Dr. Valery Ruchnov

Director, "Geochrom Service"

Ph: 117-59-79 
Appendix A - continued

VNIIgeosystem - continued

Dr. Eugenia Cheremisina

Head of Geoinformatics Laboratory

$\mathrm{Ph}:$ 952-66-39 and 954-21-50

Fax: 958-37-11

St. Petersburg Mining Institute

21-Line, dom 2

199026, St. Petersburg, Russia

Dr. Vladimir S. Litvinenko

Prof. Yuriy D. Dyadkin

Rector

Ph: (812) 213-60-78

Fax: (812) 218-54-63

Head of Mining Thermophysics Research Lab President, Russian Geothermal Association $\mathrm{Ph}$ : (812) 218-86-52, 355-01-12

Fax: (812) 213-26-13

Vladimir Klimov

Drilling Engineering and Technology Department

$\mathrm{Ph}:$ 2-188-261

VNIIgeofizika Neftegeofizika

22, Pokrovka str.

Moscow, 101000, Russia

Dr. Alkexy Mikhaltsev

Director

Fax: 7 (095) 412-08-72 
This page intentionally left blank. 


\section{DISTRIBUTION}

1 - Mr. Lawrence M. Jones

LMJ, Inc.

952 Echo Lane, Suite 335

P.O. Box 79667

Houston, Texas 77279

1 - Mr. Jamie R. Allison Amoco Production Company

Tulsa Research Center 4502 East 41st Street

P.O. Box 3385

Tulsa, Oklahoma 74102-3385

1 - MS0701 6100 R. K. Lynch

1 -MS1033 6111 James C. Dunn

5 -MS1033 6111 Diane M. Schafer

30 - MS1033 6111 David A. Glowka

5 - MS0751 6117

1 - MS0467 5091

Lawrence W. Teufel

Dennis Croessman

1 - MS9018 8523-2 Central Technical Files

5 -MS0899 13414 Technical Library

1 - MS0619 12615 Print Media

2 - MS0100 7613-2 Document Processing for DOE/OSTI

1 - Ms. Cheryl L. Stark

Baker Hughes - Oilfield Operations

3900 Essex Lane, Suite 800

P.O. Box 4740

Houston, Texas 77210-4740

1 - Paul B. Crawford, Ph.D.

Professor Emeritus

Texas A \& M University

Petroleum Engineering Department

College Station, Texas 77843-3116

1 - Mr. Ed Hartley

Pennzoil International

Pennzoil Place

P.O. Box 2967

Houston, Texas 77252-2967

1 - James T. Olsta

Environmental Planning Group

205 Park Avenue

Barrington, Il 60010

1 - U.S. Department of Energy

Geothermal Division

Attn: Alan Jelacic

Forrestal Bldg., C-122

1000 Independence Avenue S.W.

Washington, D.C. 20585 